UDC 316:061.2(470.45)

LBC 60.561 .36

\title{
CONTINUITY OF VETERAN AND YOUTH MOVEMENT: THE EXPERIENCE OF THE VOLGOGRAD REGIONAL PUBLIC ORGANIZATION "UNION OF KOMSOMOL GENERATIONS"
}

\author{
Olga I. Sgibneva \\ Volgograd State University, Volgograd, Russian Federation
}

\begin{abstract}
The article analyzes the activities of the public organization, which includes veterans of the Komsomol of the Volgograd region. The purpose of the organization is to preserve the best traditions of the Komsomol of education of children and youth in the spirit of citizenship and patriotism, the formation of moral culture, love for work, love for their Fatherland. Created in 1994, during the period of active reassessment of the values of the Soviet era, when Komsomol ceased its activities after the extraordinary "liquidation" Congress, the "Union of Komsomol generations" united active people who had passed the school of Komsomol, who were well aware of working with young people and were ready to help new youth organizations in the conditions of transformation processes in the country, to resist the deformation of public consciousness. VROO "Union of Komsomol generations" builds its work on the basis of the Charter, its main objectives are to promote the strengthening of ties between different generations, to attract veterans of the Komsomol to the Patriotic education of young people, to transfer the best traditions of older generations. The Union actively cooperates with youth organizations of modern Russia - regional branches of the Federation of children's organizations, the Lenin Communist youth Union, the regional pioneer organization and others. Joint participation in Patriotic events, in the work of protection of monuments of history and culture, employment, travelling to the native land, the patronage of the veterans contributes to the preservation of continuity of generations, broadcasting and exploiting the heritage of the largest youth organizations in the country, successfully participating in the solution of complex problems of an economic, social and cultural development of the state, along with all the people with the last honor trials of battle. Special objects of attention of veterans and youth were the memorial on the Soldier's field and the monument to Komsomol defenders of Stalingrad, created on the initiative of the Komsomol on the funds earned by young people on voluntary labor actions. Common cause of veterans and youth was the preparation for the celebration of the 100th anniversary of the Komsomol. This event has acquired a national scale and has served as an important factor in the unification of regional organizations of veterans of the Komsomol in the All - Russian public organization "Pupils of the Komsomol-My Fatherland".

Key words: continuity of generations, traditions, heritage, historical memory, humanitarian crisis, state cultural policy.
\end{abstract}

УДК 316:061.2(470.45)

ББК 60.561 .36

ПРЕЕМСТВЕННЫЕ СВЯЗИ

В ВЕТЕРАНСКОМ И МОЛОДЕЖНОМ ДВИЖЕНИИ: ОПЫТ РАБОТЫ ВОЛГОГРАДСКОЙ РЕГИОНАЛЬНОЙ ОБЩЕСТВЕННОЙ ОРГАНИЗАЦИИ «СОЮЗ КОМСОМОЛЬСКИХ ПОКОЛЕНИЙ»

\section{Ольга Ивановна Сгибнева}

Волгоградский государственный университет, г. Волгоград, Российская Федерация 
Аннотация. В статье анализируется деятельность общественной организации, в состав которой входят ветераны комсомола Волгоградской области. Целью организации является сохранение лучших традиций комсомола по воспитанию детей и молодежи в духе гражданственности и патриотизма, формированию нравственной культуры, любви к труду, любви к своему Отечеству. Созданная в 1994 г., в период активной переоценки ценностей советской эпохи, когда комсомол прекратил свою деятельность после внеочередного «ликвидационного» съезда, «Союз комсомольских поколений» объединил активных людей, прошедших школу комсомола, хорошо знающих работу с молодежью и готовых помогать новым молодежным организациям в условиях трансформационных процессов в стране, противостоять деформации общественного сознания. Волгоградская региональная общественная организация «Союз комсомольских поколений» строит свою работу на основании Устава, основными его задачами являются содействие укреплению связей разных поколений, привлечение ветеранов комсомола к патриотическому воспитанию молодежи, к передаче ей лучших традиций старших поколений. Союз активно взаимодействует с молодежными организациями современной России - региональными отделениями Федерации детских организаций, Ленинского коммунистического союза молодежи, областной пионерской организацией и др. Совместное участие в патриотических акциях, в работе по охране памятников истории и культуры, трудовых акциях, путешествиях по родному краю, шефстве над ветеранами способствует сохранению преемственности поколений, трансляции и использованию наследия самой крупной молодежной организации страны, успешно участвовавшей в решении сложных проблем экономического, социального и культурного развития государства, вместе со всем народом с честью прошедшей военные испытания. Особыми объектами внимания ветеранов и молодежи стали мемориал на Солдатском поле и памятник комсомольцам - защитникам Сталинграда, созданные по инициативе комсомола на средства, заработанные молодежью на добровольных трудовых акциях. Общим делом ветеранов и молодежи стала подготовка к празднованию 100-летия основания комсомола. Это событие приобрело государственный масштаб и послужило важным фактором объединения региональных организаций ветеранов комсомола в Общероссийскую общественную организацию «Воспитанники комсомола - Мое Отечество».

Ключевые слова: преемственность поколений, традиции, наследие, историческая память, гуманитарный кризис, государственная культурная политика.

В Основах государственной культурной политики, утвержденных Указом Президента Российской Федерации от 24.122014 г., отмечается, что перед страной стоит задача в исторически короткий период осуществить экономическую и социальную модернизацию страны, выйти на путь интенсивного развития, обеспечивающего готовность государства и общества ответить на вызовы современного мира. Это возможно только при условии планомерных и последовательных инвестиций в человека, в качественное обновление личности [9]. Недооценка человеческого фактора создала реальную угрозу гуманитарного кризиса. К наиболее опасным для будущего России проявлениям этого кризиса в документе названы деформация исторической памяти и атомизация общества - разрыв социальных связей, в том числе между поколениями [9].

Социально-политические события конца 80-х - 90-х гг. прошлого века привели к кризису ценностей, переосмыслению событий отечественной истории XX в., следствием чего стал разрыв поколенческих связей, формирование негативного отношения к событиям советского прошлого, прежде всего в сознании молодежи. Прошло более двух десятилетий, изменилась ситуация в стране - и другие, основанные на документах, взвешенные оценки прошлого постепенно утверждаются в общественном сознании. Но уже выросло поколение детей тех молодых людей, сознание которых в 90-е гг. формировалось на основе отрицания всего советского. И проблема атомизации общества становится еще более сложной, она затрагивает уже несколько поколений. Одними историческими исследованиями, основанными на объективной оценке динамики общества и государства, эту проблему не решить. Нужна кропотливая и заинтересованная работа многих социальных субъектов, ориентированная на конечную цель, которая сформулирована Основами государственной культурной политики, Законом РФ «Об образовании» и другими законодательными актами: «повышение гражданского самосознания, готовности и способности людей к активному участию в процессах общественного развития, развитие национальной гордости, формирование нравственной, ответственной, самостоятельно мыслящей, творческой личности; передача от поколения к поколению традици- 
онных для российской цивилизации ценностей, норм и традиций» [9].

Большую роль в преодолении разрыва поколенческих связей могут сыграть ветеранские организации - в том случае, если они не замыкаются на своих внутренних проблемах, а активно работают с молодежью, взаимодействуют с молодежными общественными объединениями.

Такой организацией в Волгоградской области с полным правом можно считать Волгоградскую региональную общественную организацию «Союз содействия укреплению связей разных поколений людей» (Союз комсомольских поколений). И сегодня, когда в России идет активная подготовка к празднованию 100-летия создания комсомола, деятельность Союза комсомольских поколений (далее - СКП), основанная на лучших традициях ВЛКСМ, представляет особый интерес для исследований.

Организация создана в сложные для российского общества годы - в 1994 году. Вот что вспоминает один из инициаторов создания СКП, бывший комсомольский и партийный работник Анатолий Петрович Невструев: «Весть о том, что комсомол прекращает свою деятельность, многими комсомольцами и ветеранами комсомола была воспринята с глубокой болью и озабоченностью. Опыт, накопленный комсомолом за годы его деятельности, поистине неоценим. События в стране показывали, что правду о комсомоле кто-то должен говорить. А ведь почти все мы, кто прошел школу комсомольской работы, знали друг друга, дружили. И в 1994 г. было принято решение создать СКП, который бы объединил ветеранов комсомола и молодежные патриотические организации. Мы обратились к молодым волгоградцам и бывшим членам ВЛКСМ, не расставшимся с идеалами юности. В том обращении говорилось: «Мы понимаем, что каждое поколение несет на себе ответственность своей эпохи. Но в большом и главном мы едины. Комсомол, пионерия уникальное достояние нации. Продолжать их лучшие традиции - наша общая патриотическая задача» [2, с. 3].

Действительно, в сентябре 1991 г. деятельность комсомола была прекращена. «Стартовым сигналом к подготовке ликвида- ционного съезда стало заявление Бюро ЦК ВЛКСМ 3 сентября 1991 года, затем подтвержденное VI пленумом ЦК. В нем говорилось, что попытка августовского государственного переворота означает необратимость демократических изменений в обществе. Указывалось, что завершился этап полумер и полуреформ. В стране объективно стали неизбежны радикальные экономические и политические реформы. Из этого делался вывод: «Исчерпан и путь эволюционного, постепенного преобразования ВЛКСМ» [4].

27 сентября 1991 г. в Москве начал свою работу XXII чрезвычайный съезд ВЛКСМ. В его работе участвовали 552 делегата от 17 субъектов Федерации и 9 организаций, напрямую входящих в ВЛКСМ. В докладе «О судьбе комсомола» первый секретарь ЦК В.М. Зюкин сказал: «Старая система разрушена и вместе с ней из политического бытия должна уйти и организация, которая была элементом системы. Существование комсомола даже в новых одеждах объективно невозможно» [4].

Поспешное стремление лидеров комсомола 90-х гг. поставить точку в истории Всесоюзного ленинского коммунистического союза молодежи стало драматическим событием для людей самых разных поколений. Миллионы советских людей прошли в комсомоле первую школу гражданственности и патриотизма, получили навыки организаторской работы, опыт социальных коммуникаций. Комсомол дал возможности развития творческих способностей молодых людей, способствовал их профессиональному росту. Не случайно и сегодня многие люди, достигшие профессиональных высот, с гордостью говорят о том, что они были лауреатами премий Ленинского комсомола. Эти премии стали первым подтверждением профессиональных достижений молодых ученых, инженеров, рабочих, педагогов, врачей, деятелей искусств. Так, среди более чем 40 волгоградцев, удостоенных премий Ленинского комсомола, были молодые ученые - Владимир Петров (1979 г.) и Владимир Лысак (1989 г.). Сегодня доктор медицинских наук, профессор, академик РАН В.И. Петров возглавляет Волгоградский государственный медицинский университет; доктор технических наук, профессор, член-кор- 
респондент РАН В.И. Лысак - ректор Волгоградского государственного технического университета. Не было области общественных отношений, будь то политика, международные связи, экономика, культура, туризм, физкультура и спорт, педагогика и воспитание, в которой не участвовал бы комсомол. Огромен вклад комсомола в промышленное и культурное строительство, в победу советского народа в Великой Отечественной войне; в послевоенный период по всей стране раскинулась сеть ударных комсомольских строек, результативность которых показало уже постсоветское время.

Кризис комсомола в последнее десятилетие советского периода был порожден общим кризисом социалистической системы, охватившим сферу экономики, политики, национальных отношений, нравственных устоев. В обществе обострились социальные проблемы, особенно чувствительно сказавшиеся на молодом поколении. Произошел опасный для преемственных связей разрыв поколений, «в условиях перестройки и демократизации советского общества комсомол оказался не в состоянии удержать молодежь в сфере своего влияния» [4].

Немногочисленный чрезвычайный съезд ВЛКСМ, созванный «молодыми энтузиастами» либерализации страны [3], уничтожил организацию, которая объединяла более 30 млн человек. Но не все комсомольцы в регионах согласились с этим решением, с оценкой роли комсомола и однозначным отрицанием его будущего. Раскол общественного сознания затронул и молодежь. И во многих областях стали возникать новые региональные молодежные объединения, чьи мировоззренческие позиции опирались на традиции комсомола [7, с. 86-92].

В эти сложные годы ветераны комсомола Волгограда приняли решение о создании организации, которая взяла бы на себя ответственность за сохранение и развитие традиций комсомола, за поддержку преемственности поколений и передачу будущему правды о самой крупной в мире молодежной организации.

На тот период это было смелое решение, причем такое объединение ветеранов комсомола и молодежных патриотических объе- динений Волгоградской области было первым в России. И вскоре в Волгоград стали приезжать представители из разных регионов, чтобы ознакомиться с работой и использовать опыт волгоградцев в своих регионах [6, с. 2]. Учредителями организации выступили бывшие комсомольские работники разных поколений: Л.В. Анипкина, В.И. Бацунов, Г.В. Бондаренко, А.В. Варакин, В.Ф. Гордеев, А.П. Невструев, М.Е. Чулкова, Н.А. Юрков, Г.А. Ясковец. Первым председателем СКП на общем собрании организации был избран Анатолий Петрович Невструев, который возглавлял СКП до 2003 года. С 2003 по 2006 г. во главе СКП стоял Виталий Иванович Бацунов, с 2006 по 2007 г. - Василий Федорович Гордеев, с 2007 г. по настоящее время председателем СКП является Галина Ильинична Хорошева.

В 1999 г. СКП был зарегистрирован как Волгоградская региональная общественная организация (к этому времени в ее структуре было более 10 отделений в районах Волгоградской области). В 2011 г. организация была успешно перерегистрирована; утверждена новая редакция Устава Волгоградской региональной общественной организации «Союз содействия укреплению связей разных поколений людей» (СКП), действующая по настоящее время.

Уставом определено, что Волгоградская региональная общественная организация «Союз содействия укреплению связей разных поколений людей» (СКП) представляет собой добровольное самоуправляемое общественное объединение граждан, ветеранов Великой Отечественной войны, тружеников тыла, детей Сталинграда, ветеранов комсомола, объединившихся на основе общности интересов для реализации целей содействия укреплению связей разных поколений людей; привлечению ветеранов комсомольских поколений к участию в патриотическом и гражданском воспитании молодежи, передачи ей жизненного опыта и лучших традиций старших поколений; участию в защите общих социальных интересов $[10$, с. 2$]$.

Союз строит свою работу на принципах добровольности, равноправия, самоуправления и законности. Уставом Союзу дано право создавать свои местные отделения на территории Волгоградской области: в 2018 г. их число 
достигло 30, это районные и городские отделения СКП, самые крупные из которых - отделения г. Волжского, г. Камышина, Красноармейского и Центрального районов г. Волгограда, Котельниковского и Калачевского районов Волгоградской области. С момента государственной регистрации в 1999 г. СКП имеет права юридического лица. Для организации деятельности СКП Администрацией Волгоградской области выделено помещение в Доме ветеранов по адресу: Волгоград, ул. Набережная им. 62-й Армии, д. 1 («Дом Чуянова») $[10$, с. $2,9-10]$.

В Уставе зафиксированы основные задачи, которые решает Союз для достижения уставных целей:

- ведет благотворительную работу, создает фонды общественной организации; защищает социально-экономические, трудовые, политические, личные права и свободы комсомольцев старшего поколения, ветеранов Великой Отечественной войны, тружеников тыла, детей Сталинграда, ветеранов комсомола, содействует развитию социальной активности молодежи, нравственному и гражданскому воспитанию;

- содействует укреплению материальной базы молодежных и ветеранских организаций, развитию форм и методов их работы путем участия в грантовых программах, конкурсах и смотрах;

- участвует в работе по охране и использованию в воспитательных и просветительских целях памятников, обелисков, памятных знаков, мемориальных досок воинам-комсомольцам, труженикам тыла, созданию музеев боевой и трудовой славы комсомольцев и молодежи [10, с. 2-3].

Кроме того, СКП участвует в работе органов представительной и исполнительной власти при обсуждении вопросов жизни молодежи и ветеранов в соответствии с действующим законодательством, рекомендует своих представителей для участия в работе общественных советов, органов по делам молодежи, органов по делам ветеранов в структурах государственной власти и местного самоуправления области. Представители СКП приглашаются на заседания депутатских групп, общественных палат Волгоградской области, Волгограда и Волжского, участвуют в работе оргкомитетов областных и городских мероприятий [10, с. 10-11].

В Уставе определены условия приема в члены СКП, их права и обязанности, структура управления деятельностью Союза. Высшим органом управления является Конференция, созываемая Президиумом Союза не реже одного раза в два года. Коллегиальным постоянно действующим руководящим органом Союза, управляющим его делами между конференциями, является президиум в главе с председателем, избираемый сроком на 2 года $[10$, c. 7$]$.

Одно из важных направлений работы СКП - оказание помощи ветеранам войны и труда, ветеранам комсомола, в силу обстоятельств оставшихся без поддержки родных или потерявших здоровье. К шефству над ветеранами привлекаются и члены молодежных организаций. Работа эта многовекторная: помощь в решении бытовых вопросов, медицинская поддержка, организация юбилейных мероприятий, поздравления с праздничными датами и обычное общение, которого так не хватает одиноким пожилым людям. Комсомольцы-волонтеры используют такое общение и для записи воспоминаний ветеранов, которые потом становятся частью музейных фондов молодежных организаций, публикуются в средствах массовой информации.

Стали традиционными совместные с молодежью празднования важных исторических дат в истории страны, Волгоградской области и истории молодежного движения: годовщина победы в Сталинградской битве 2 февраля, День Победы 9 мая, День России 12 июня, годовщина трагической бомбардировки Сталинграда немецко-фашистскими войсками 23 августа 1942 г., годовщина создания комсомола 29 октября, начало контрнаступления Красной армии под Сталинградом 19 ноября 1942 года. В эти дни молодежь и ветераны приходят с цветами и венками к памятникам, связанным с этими событиями: к памятнику комсомольцам-защитникам Сталинграда на ул. Комсомольской, на Солдатское поле в Городищенском районе, памятнику А. Маресьеву в Камышине, памятнику жителям Сталинграда, погибшим в августе 1942 г. и другим мемориальным местам. Многие из этих памятников создавались в разные годы 
по инициативе комсомола Волгограда и области, на средства, заработанные комсомольцами на субботниках [5; 8, с. 314-316].

Благодаря СКП в 2000-е гг. установлены мемориальные доски на станциях скоростного трамвая «Комсомольская» и «Пионерская», на улице Комсомольская в Волгограде. И это не случайно: молодежь города, современные волгоградцы не должны забывать о вкладе комсомольцев в победу над фашизмом, в восстановление разрушенного войной города. В декабре 1942 г. в письме в газету «Комсомольская правда» из воюющего Сталинграда командующий 62-й армией генераллейтенант В.И. Чуйков писал: «Вы просите сообщить мое мнение о той роли, какую сыграли в боях за Сталинград комсомольцы 62-й армии. Могу сказать одно: комсомольцы со своим фантастическим бесстрашием и мужеством, толкавшим их во имя победы Родины на легендарные, неслыханные в истории войн подвиги, прекрасно помогли 62-й армии добиться в защите города тех успехов, о которых сегодня говорит весь мир. Потомки наши никогда не забудут величия духа и сказочной крепости комсомольских сердец у стен Сталинграда, выдержавших и отбросивших вспять всю военную мощь Германии. Когда 62-я армия, с треском вышибив фашистов, снова с высоко поднятыми знаменами пройдет через весь Сталинград, мы лучшую улицу в городе назовем Комсомольской» [1].

Завет командарма выполнен: в центре Волгограда одна из улиц, ведущих к Волге, названа в честь комсомольцев - защитников города. Когда на этой улице была построена станция скоростного подземного трамвая, она тоже получила наименование «Комсомольская». Но проходят годы, все меньше среди нас живых свидетелей героической военной истории. И установленные разными поколениями комсомольцев мемориальные доски их напоминание потомкам о подвиге тех, кто отдал свои молодые жизни ради будущего родной страны.

Члены СКП - частые гости в штабе на Посту № 1 у памятника защитникам Царицына - Сталинграда. Когда-то именно комсомольцы Волгограда выступили инициаторами создания комсомольско-пионерских постов памяти у Вечного огня, и первый в стране Пост
№ 1 открыт в Волгограде в 1965 г. по решению Волгоградского горкома комсомола. В 1991 г. на волне разрушения советского прошлого по всей стране молодежные вахты памяти у монументов в честь героев Великой Отечественной войны были отменены. Отменены, но не забыты. В Волгограде и по всей стране патриотическая общественность активно боролась за восстановление традиций молодежной Вахты памяти. И 6 октября 1999 г. Пост № 1 в Волгограде возобновил свою работу. Сегодня он является опорным федеральным центром по гражданскому и духовно-нравственному воспитанию молодежи. Более 200 тыс. юных волгоградцев несли почетную Вахту памяти на Аллее Героев, изучали историю Сталинградской битвы не только по книгам и документам, но и в личном общении в штабе Поста с теми, кто прошел военными дорогами, кто работал в тылу, кто восстанавливал город после освобождения [11, c. 167-168].

Члены СКП вместе с молодежными организациями участвуют в акции «Бессмертный полк», осуществляют озеленение и благоустройство памятных мест, организуют встречи с молодежью в школах, библиотеках, домах детского творчества; вместе с музейными работниками готовят выставки в областных и районных музеях, в общественных пространствах региона. Стали традиционными конференции и «круглые столы» ветеранов комсомола и актива молодежных организаций, дискуссии по проблемам современного молодежного движения, вопросам воспитания детей и молодежи, совместные путешествия по историко-культурным местам региона, ежегодные спартакиады поколений. Такое расширение границ общения укрепляет преемственные связи людей разного возраста, способствует взаимопониманию на основе общих интересов и ценностей.

Важная часть работы СКП - подготовка и издание книг о комсомоле и комсомольцах. Издания осуществляются за счет спонсорских взносов членов Союза и грантов Администрации Волгоградской области для некоммерческих общественных организаций. Результатом исследования участия комсомольцев в Сталинградской битве и послевоенном восстановлении города стали книги 
одного из основателей СКП Г.А. Ясковца «Люди из легенды» (2006 г.), «Память длиною в жизнь. От ВЛКСМ до СКП» (2009 г.), «С тобой, моя Родина, до конца» (2012 г.). В 2015 г. вышла в свет книга об истории пионерской организации Волгоградской области «Горнисты трубят сбор». Значительная часть тиража этих книг передана в областные, городские и районные библиотеки, музеи, школы, высшие и средние специальные учебные заведения.

В настоящее время завершается работа над книгой об истории Волгоградской областной комсомольской организации «Это наша с тобой биография», выпуск которой планируется в октябре 2018 г. - к 100-летию создания комсомола. Издание подготовлено большим авторским коллективом, в составе которого ветераны комсомола, бывшие комсомольские работники и пионерские вожатые, ученые волгоградских вузов, работники волгоградских архивов, члены современных молодежных организаций.

Прошло почти 27 лет со дня прекращения деятельности ВЛКСМ, прошло последнее десятилетие XX в., когда деятельность комсомола интерпретировалась как деятельность политической организации, основанной на тотальном контроле за сознанием молодежи, на полном пресечении свободы мысли и творчества. И сегодня уже более взвешенно и спокойно, с учетом документов и реальных фактов, без политической ангажированности анализируется сложная и многообразная работа комсомола, в которой были и успехи, и недостатки. Во всех крупных достижениях Советского Союза есть вклад комсомольцев: это промышленное строительство, создание транспортных магистралей, ликвидация безграмотности, победа над фашизмом, научный прорыв, разработка месторождений полезных ископаемых, освоение космоса. Но встречалось и «бюрократическое рвение», и подмена результатов красивыми лозунгами. Накопленный комсомолом опыт - и героический, и трагический - это часть истории нашей страны и она должна быть известна новым поколениям молодежи без фальсификаций, деформаций и искажений [2]. Многие современные молодежные организации сегодня обращаются к опыту работы комсомола, к тем формам и методам работы, которые востребованы и в современной ситуации (ученические производственные бригады, школьные лесничества, студенческие строительные отряды, тимуровское движение - волонтерство, поисковая работа, шефство над памятниками истории и культуры, творческие и научные конкурсы и др.). Не случайно по всей стране развернулась активная подготовка к празднованию 100-летия ВЛКСМ. Созданная пять лет назад Общероссийская общественная организация «Воспитанники комсомола - Мое Отечество» [3], объединившая все ранее созданные региональные сообщества ветеранов комсомола, возглавила эту работу. В состав этой организации вошел и СКП Волгоградской области.

Руководители ООО «Воспитанники комсомола - Мое Отечество», бывшие первые секретари Центрального комитета комсомола разных лет: Е.М. Тяжельников, Б.Н. Пастухов, B.M. Мишин - успешно решают организационные вопросы по подготовке к 100-летию комсомола в Администрации Президента РФ, в Правительстве России, в Федеральном собрании РФ. Но в этой работе не участвуют те секретари ЦК ВЛКСМ и комсомольские работники, которые провели на последнем съезде комсомола в 1991 г. решение о ликвидации организации.

По инициативе ветеранов комсомола губернаторы во многих регионах приняли специальные постановления о подготовке к празднованию 100-летия комсомола. Такой документ подписал и губернатор Волгоградской области. Постановлением № 1020 от 29.122016 г. создан оргкомитет во главе с заместителем губернатора области, утвержден план основных мероприятий по подготовке к празднованию 100-летия комсомола. Эта работа объединила волгоградскую общественность, вместе с ветеранами в ней участвуют молодежные общественные организации (ЛКСМ, ВООО «Федерация детских организаций», областная пионерская организация, ВОО «Созвездие талантов» и др.), учреждения культуры и образования, архивные учреждения. В ознаменование 100-летия ВЛКСМ в области пройдут встречи ветеранов комсомола с молодежью, научные конференции и дискуссии, будут подготовлены выставки в музеях и библиотеках, в том числе в Волгоград- 
ском областном краеведческом музее, музее Сталинградской битвы, в Волгоградской областной библиотеке им. М. Горького; концерты с участием лауреатов премий Ленинского комсомола и Волгоградской областной комсомольской организации; будут подготовлены специальные радио- и телепередачи, выпущены книги и специальная сувенирная продукция. 29 октября 2018 г., в день рождения комсомола, в Волгограде пройдет областной слет комсомольских поколений «Это наша с тобой биография».

Современное общество изменилось, но базовые ценности, которые определяют единство наций, с каждым годом приобретают все большее значение. Честность, порядочность, справедливость, милосердие, уважение к человеку и чувство собственного достоинства, любовь к Родине - эти ценности хранит историческая память нашего народа, они определяют преемственность поколений. Именно на этих ценностях строилась комсомольская работа, определялись приоритеты в каждом регионе, в каждой комсомольской организации. Комсомол стал судьбой для нескольких поколений, стал частью истории и культуры нашей страны. Сохранить самое ценное - любовь к людям, желание самоотверженно трудиться, познавать мир и развивать свои творческие способности, те качества, которые противостоят социальному эгоизму, корысти и цинизму, передать лучшие традиции молодым - в этом видит свою задачу СКП Волгоградской области. И эта работа является важным фактором преодоления атомизации общества, укрепления ценностных основ российского социума, сохранения исторической памяти, гармонизации общественных отношений.

А 27 октября 2018 г. ветераны комсомола из всех регионов России, делегации из стран СНГ и ряда других стран соберутся на праздновании 100-летия ВЛКСМ в Москве, в Кремлевском дворце. Вместе с ветеранами комсомола будут в составе делегатов и участники современных молодежных организаций.

\section{СПИСОК ЛИТЕРАТУРЫ}

1. Из письма командующего 62-й армией генерала-лейтенанта В.И. Чуйкова в редакцию «Комсомольской правды». Декабрь 1942 // Во славу
Родины (1941-1945). - М. : Воениздат, 1961. С. 155-156. - Электрон. текстовые дан. - Режим доступа: http://comstol.info/2013/02/biblioteka/ 5799 (дата обращения: 12.06.2018). - Загл. с экрана.

2. Комсомол - моя судьба. - Волгоград : ООО «Вести-Пресс», 2003.-28 с.

3. Международный оргкомитет «Комсомолу - 100». - Электрон. текстовые дан. - Режим доступа: http://komsomol-100.clan.su/news/gotovimsja k_100_letiju_komsomola/2018-03-22-2406 (дата обращения: 04.06.2018). - Загл. с экрана.

4. Мухамеджанов, М. М. Комсомол: последние десять лет (1981-1991) / М. М. Мухамеджанов // Информационный гуманитарный портал «Знание. Понимание. Умение». - 2008. - № 6. - Электрон. текстовые дан. - Режим доступа: http://www. zpu-journal.ru/e-zpu/2008/6/Mukhamedzhanov Komsomol/ (дата обращения: 15.05.2018). - Загл. с экрана.

5. Сгибнева, О. И. Хранители исторической памяти: судьба памятника - судьба поколений / О.И. Сгибнева // Социология власти. Вестник социологического центра РАГС. - 2003. - № 2. C. 131-139.

6. Союзу комсомольских поколений -20 лет. Волгоград : СКП, 2014. - 24 c.

7. Справочник общественных организаций и политических партий Волгоградской области / сост. О. И. Сгибнева [и др.]. - Волгоград : Изд-во ВолГУ, 2009. - 352 с.

8. Сталинградская битва: июль 1942 - февраль 1943 : энциклопедия / под ред. М. М. Загорулько. Волгоград : Издатель, 2012. - 80 c.

9. Указ Президента РФ от 24.12.2014 № 808 «Об утверждении Основ государственной культурной политики». - Доступ из справ.-правовой системы «КонсультантПлюс» (дата обращения: 17.05.2018).

10. Устав Волгоградской региональной общественной организации «Союз содействия укреплению связей разных поколений людей» (Союз комсомольских поколений). Утвержден общим собранием учредителей 29.10.2011 г., протокол № 1. - Волгоград : СКП, 2012.- 12 c.

11. Энциклопедия Волгоградской области /гл. ред. О. В. Иншаков. - Волгоград : Издатель, 2007. - 447 с.

\section{REFERENCES}

1. Iz pisma komanduyushchego 62-y armiey generala-leytenanta V.I. Chuykova v redaktsiyu «Komsomolskoy pravdy». Dekabr 1942 [From the Letter of Commander of the $62^{\text {nd }}$ Army, LieutenantGeneral V.I. Chuykov to the Editorial Board of Komsomolskay Pravda. December 1942]. Vo slavu Rodiny (1941-1945). Moscow, Voenizdat Publ., 1961, 
pp. 155-156. URL: http://comstol.info/2013/02/ biblioteka/5799 (accessed 12 June 2018).

2. Komsomol - moya sudba [The Komsomol Party Is my Fate]. Volgograd, Vesti-Press, 2003. 28 p.

3. Mezhdunarodnyy orgkomitet «Komsomolu100» [The International Organizing Committee Komsomol - 100]. URL: http://komsomol-100.clan.su/ news/gotovimsja_k_100_letiju_komsomola/2018-0322-2406 (accessed 4 June 2018).

4. Mukhamedzhanov M. M. Komsomol: poslednie desyat let (1981-1991) [Komsomol: the Last Ten Years (1981-1991)]. Informatsionnyy gumanitarnyy portal «Znanie. Ponimanie. Umenie», 2008, no. 6. URL: http:// www. zpu-journal.ru/e-zpu/2008/6/Mukhamedzhanov_ Komsomol/ (accessed 15 May 2018).

5. Sgibneva O.I. Khraniteli istoricheskoy pamyati: sudba pamyatnika - sudba pokoleniy [The Keepers of Historical Memory: The Fate of the Monument - the Fate of Generations]. Sotsiologiya vlasti. Vestnik sotsiologicheskogo tsentra RAGS, 2003, no. 2, pp. 131-139.

6. Soyuzu komsomolskikh pokoleniy - 20 let [The Union of Komsomol Generations Is 20 Years Old]. Volgograd, SKP Publ., 2014. 24 p.

7. Sgibneva O.I., et al. Spravochnik obshchestvennykh organizatsiy i politicheskikh partiy Volgogradskoy oblasti [Directory of Public
Organizations and Political Parties of the Volgograd Region]. Volgograd, Izd-vo VolGU, 2009. 352 p.

8. Zagorulko M.M., ed. Stalingradskaya bitva: iyul 1942 - fevral 1943: entsiklopediya [The Battle of Stalingrad: July 1942 - February 1943: Encyclopedia]. Volgograd, Izdatel Publ., 2012. 80 p.

9. Ukaz Prezidenta RF ot 24.12.2014 № 808 «Ob utverzhdenii Osnov gosudarstvennoy kulturnoy politiki» [Presidential Decree of 24 December 2014 No. 808 'On Approval of the Fundamentals of the State Cultural Policy]. Access from reference legal system "KonsultantPlyus"(accessed 17 May 2018).

10. Ustav Volgogradskoy regionalnoy obshchestvennoy organizatsii «Soyuz sodeystviya ukrepleniyu svyazey raznykh pokoleniy lyudey» (Soyuz komsomolskikh pokoleniy). Utverzhden obshchim sobraniem uchrediteley 29.10.2011 g., protokol № 1 [The Charter of the Volgograd Regional Public Organization "The Union for the Promotion of Strengthening the Ties of Different Generations of People" (Union of Komsomol Generations). Approved by the General Meeting of the Founders on October 29, 2011, Minutes No. 1]. Volgograd, SKP Publ., 2012. 12 p.

11. Inshakov O.V., ed. Entsiklopediya Volgogradskoy oblasti [Encyclopedia of the Volgograd Region]. Volgograd, Izdatel Publ., 2007. 447 p.

\section{Information about the Author}

Olga I. Sgibneva, Doctor of Philosophy, Professor, Professor of Department of Sociology, Volgograd State University, Prosp. Universitetsky, 100, 400062 Volgograd, Russian Federation, olga.sgibneva@volsu.ru

\section{Информация об авторе}

Ольга Ивановна Сгибнева, доктор философских наук, профессор, профессор кафедры социологии, Волгоградский государственный университет, просп. Университетский, 100, 400062 г. Волгоград, Российская Федерация, olga.sgibneva@volsu.ru. 